\title{
ADS AND FUNDRAISING: A QUASI-MARKET SCHOOL SYSTEM
}

\author{
Isabel Farinha* \\ *UNIDCOM / IADE Creative University \\ Av. D. Carlos I, 4, 1200-649 Lisbon, Portugal \\ isabel.farinha@iade.pt
}

\begin{abstract}
This paper aims to produce analytical-theoretical contributions on the school as a new medium and a new channel of consumption, analyzing its central role in mediating between the state, market and civil society. The field of in-school marketing is largely unexplored in Portugal.

Thus the importance of this research and its guideline questions, rooted in a biased consumer society in the process of cultural reassignment, are as follows: which social win-win relationship practices or legitimacy/visibility ones transacted by state, market and civil society are evident in their interaction with the school system?; how do in-school marketing activities square with public-private organizations' corporate responsibility?; are the ethical parameters of legislated and self-regulated best practice principles synonymous with consensus? Another purpose of this research was also testing a Working with Schools Best Practice Principles as a self-regulatory tool aimed at school decision-makers to analyze how schools and their partners can build an ethical and responsible relationship.

The methodology combines a quantitative analysis through questionnaires addressed to school group representatives' management committees (10-15 years old children) and a qualitative approach through document analysis and semi-structured interviews with public-private stakeholders.

Our results lead us to negate hypotheses which speak of school 'marketization', despite school's weaker role in this mediation, and the prevalence of responsible in-school marketing based on best practice principles. They also lead us to support the hypothesis describing ideologically antagonistic positions and to conclude that reproduction and conception of these activities works towards an iconic shaping of schools' organizational identity and a socio-symbolical integration of the educational community into a hegemonic culture.
\end{abstract}

Keywords: in-school marketing, corporate responsibility, Working with Schools Best Practice Principles, cultural 'mcdonaldization', school 'marketization'.

\section{INTRODUCTION}

This paper is possible due to research undertaken as part of $\mathrm{PhD}$ dissertation, where due to the mediation of the public school curriculum in contemporary mediated culture we aimed to understand, through the analysis of a range of integrated marketing communications activities $[1,2,3]$, and given the depth of interaction between partners from sectors of the state, market and civil society - ongoing on the past five years - how the educational system is acting in a context of deregulation. Also, it, was our purpose to comprehend the dimensions of corporate social responsibility strategies on a global-local frame [4] of a citizen charter school that tends, in this sense, to overestimate the culturo-economic interests' rather volatile practices of commercial communication. We wanted also to understand, how different ethical and legal parameters of public and private social actors are producing partnerships and other forms of collaboration in a given performance [5] and revealing a kind of power geometry [6]. Having said that, we wanted to deeply investigate how the in-school marketing tools are crossing the school gates and the curriculum and how they are perceived by a plurality of public and private social actors. 


\section{THE SCHOOL AS A MEDIA AND A CONSUMER CHANNEL}

"In this new 'organization' the 'world' itself seems to harness the symbolic power of school and get a 'place' for it" [7].

Despite the complexity of in-school marketing and problematizations that have occurred first and foremost in the U.S. , and have been gaining ground in a number of other countries, including those belonging to the European Union [8], there is still no sociological theme line firmly devoted to study this subject. There is namely a lack of studies on the national level that analysis the importance of a youth target for business communication strategies under a corporate social responsibility umbrella [9] attending also the implications of the socialization of children and young consumer in a mediated world.

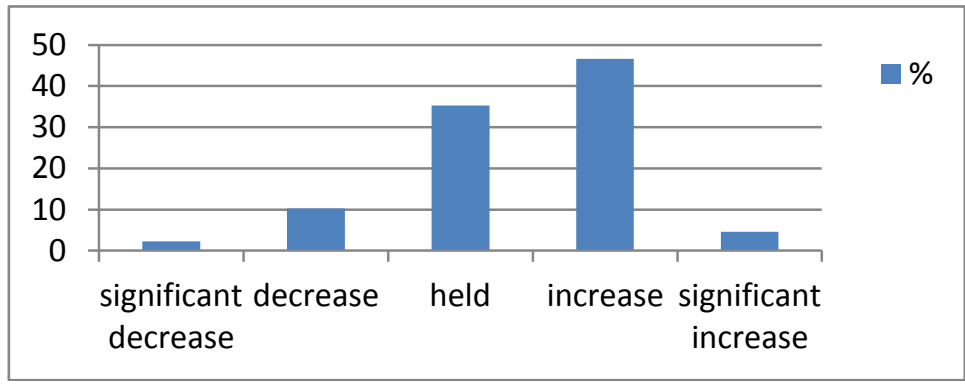

Fig.1 - Evolution shares of in-school marketing: last five years

Source: Survey by Questionnaire (measurement scale of 5 points anchored at $1=$ significant decrease, and 5 = significant increase)

Therefore, in this paper we point out the new ways to interpret the marks of a mediated culture in contemporary schools, in which the media are outside the field of traditionally media purveyors, reaching new channels and media vehicles acting as imagistic producers of meanings. It should be noted that the lateral extension of this field occurs under a thriving cultural identity construction industry, creator of myths, symbols and idols, fueled by a polysemic consumption of images.

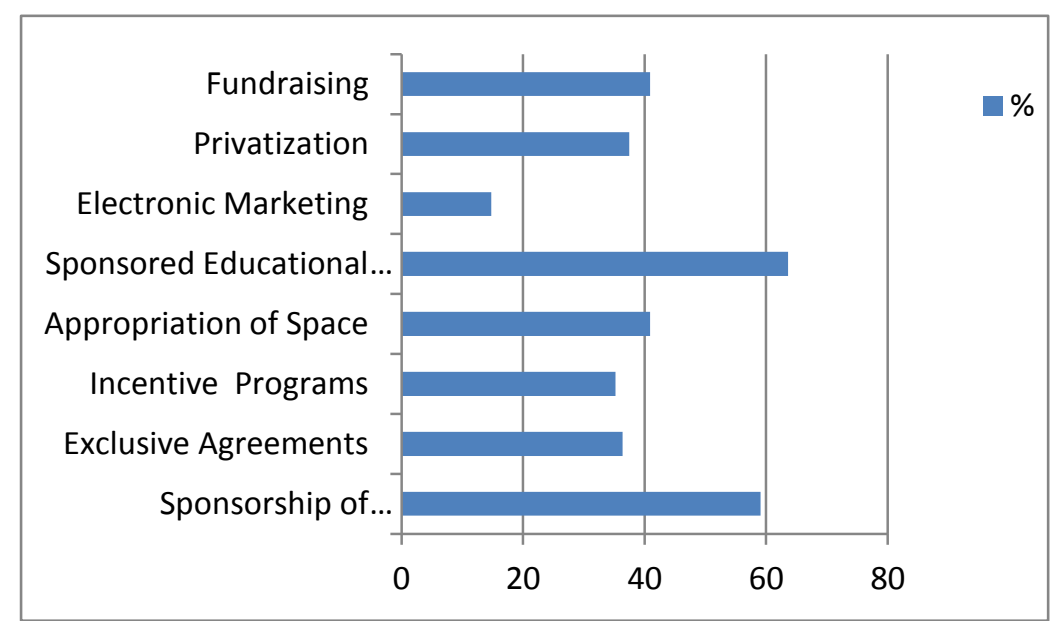

Fig.2. - Working typology of school-business interaction that takes place in schools Source: Survey by Questionnaire

Furthermore, the imagery consumption tends to occur over discursive symbolic networks incorporating a "pedagogical device" [10], who collaborate in the production of social subjects producing imaginary and pointing ways of being and living in contemporary. We are therefore faced with a particular media device, capable of functioning as a motor learning in countless cultural venues (television, computer games, world of toys, social networking, etc..), and the creation and dissemination of a series of symbolic articles, coupled with the consumption of goods and products, promoting subjectivities that serve as reference in the production of cultural identities: a consumption communication synthesis characterized by a given "pedagogy that teaches people what they need and should want, think and do to be happy" [11].

In summary, we have by the exogenous school organizations, a producer of corporate curriculum directed to an audience that under a certain apparatus of representation and mediation of knowledge, can put on circulation certain practices and homogenized educational approaches [12]. Among them there are the pedagogical, standardized and appealing kits, methodologically and technologically produced in series by 
experts in educational issues, intended to be satisfactory and instantly consumed in the wake of regulatory principles of logic of any fast food. It raises a unique contemporary "centrality of culture" [13], brought about by information and communication technology, and intertwined with all aspects of social life, mediating all social, political or economic processes. Contemporarily, yet in a discursive dimension or meaning in mutual and permanent joint, is an essential condition for the functioning of any social field.

\section{THE THREE-DIMENSIONALITY OF A MEDIATION PROCESS: THE EDUCATIONAL SYSTEM BETWEEN PUBLIC-PRIVATE PARTNERS}

Under this global agenda, the school as an organization has become a subject of advertising contained in the deregulation and privatization of public enterprises in which it promotes the establishment of partnerships between the public formal education system and other public and private organizations when combining management processes of a quasi-market [14], is capable of stimulating sport, leisure, entertainment and culture, plus a range of other educational and financial resources [15, 16, 17]. It is actually stimulated a flexible educational institution or a neoliberal market optical [18], which calls for gradual school accountability by enabling the own resources, achievement of partnerships for the organization and financing of certain services and projects. However, for this purpose one should take into consideration the contributions of the private sector and civil society, as the school is not only necessary for inspiration and creativity, but also for dissemination of goods constantly renewed [19, 20].

The publication of this public image allows the partners to achieve social legitimacy through a win-win relationship of legitimacy/visibility. It's the way in which culture, despite its usefulness, is legitimized by a "performativity" that strengthens the fiber of the social fabric [21]. This process is similar to the homogenized product, metaphorically "mcdonaldized" [22]. Although, that does not downplay the complex cultural and daily mediations at the level of reception, because consumers aren't here understood as mere passive recipients, or either as having a capacity for unlimited action, against a field of learning that teaches and persuades dreams by entertainment, seduction, fantasy and imagination. Still, we cannot overlook the importance that school has as a structural space-time [23] in the juvenile everyday life, being able to emerge into the market, as the ideal place to impact this target [24]. In fact, given both the size and permanence of this three-dimensional audience [25] it can simultaneously retain students, families and teachers.

Thus, we see in today's society of hyper or third phase of consumer capitalism [26] with closer ties and tools, resources and agents in a global liberalization of markets context, redirecting the state's role in the economy as a condition of efficiency and where the business community reemerge under the insignia of ethics, citizenship and social responsibility. Actually, in this global competitive market scenario, organizational culture tends to be guided by principles of self-regulation and differentiation of products, processes and social relations.

\section{SUMMARY}

We emphasize that the symbiosis or hybrid blends in the range of marketing activities and school communication identified, in which culture is managed as a resource showing different goals of economic and social investment and achieving varying levels of return, is precisely, in our opinion, one of the ways that the school found to respond to renewed requests in a liquid modernity [27]. School, as we have seen, is framed in a supply and demand market, which is not confined to culturally reproduce these actions, while also being a producer of such cultural practices and being recognized as proactive in seeking socioeducational partnerships, although a certain unpreparedness in literacy media to decode certain communicational proposals.

Having said that, one should note that that we invalidate the hypothesis that - despite noting the role and cognitive function to the teaching-learning process - found that this does not happen in parallel by the application of codes of good practice. Nevertheless, and according to the panel of discursive representations analyzed, the points of consensus and conflict result of the dynamics of actors from private and public interests in the core of social interaction that do not seem to match on how the actors interpret what happens to them and what happens around.

Moreover, the contribution of this discursive deconstruction and reconstruction along with the other quantitative data allowed us to confirm the hypothesis that sustains the pulse of ideologically antagonistic positions, as the school in a controversial and perhaps improbable world - where the ideology of globalization is pressing social actors trough a renewed and persistent adaptation to changes and technological mediations - especially constitutes a locus marked articulated to economic power relations politically favorable to maintaining hegemonic cultural values. So, the intersection of communication with education 
engines themselves through construction and meaning of social life, revealing that school can symbolically be associated to serve and operate its own cultural projection.

Concomitantly, this imagery of consumer brands translated a collection of legal representation is pointing the school as a specialized hegemonic agency in the production and dissemination of culture. This evaluated and competitive school loses on one hand, it places socialization while forming agent, and gains on the other, a symbolic legitimacy in contemporary consumer society to merge in permanent tension, the trade well and collective well. Although, the results obtained lead us to refute the hypothesis that points to a "marketization" of public schools, despite increased partnerships of sporadic nature, hence not revealing the prevalence of political-pedagogical long term projects, but rather a plurality of forms of association and cooperation, that can foresee relations of asymmetry. In any case, we cannot condone being in imminent presence of an overlap of power by supra-state business groups, that are able to minimize the decision of the board of management and school administration regarding the socio-educational partnerships undertaken in context of a proactive school that advocates the achievement of autonomy.

\section{ACKNOWLEDGEMENT}

This research is the result of the dissertation - Media escola: espaço de consumo de uma cultura "mcdonaldizada"? [The school as medium: the consumer space of a 'mcdonaldized' culture?], defended in ISCTE-IUL in Lisbon, on 23rd May 2013.

\section{REFERENCES}

Molnar, Alex \& Garcia, David R. (2005), Empty calories: Commercializing activities in America's schools: The eighth-annual report on schoolhouse commercialism trends, 2004-2005, Arizona State University, CERU-Commercialism in Education Research Unit, pp.1-51, (Online), http://nepc.colorado.edu/files/EPSL-0511-103-CERU.pdf.

Molnar, Alex (2006a), The ninth annual report on schoolhouse commercialism trends: 2005-2006, Arizona State University, CERU-Commercialism in Education Research Unit, pp.1-53, (Online), http://epsl.asu.edu/ceru/Annual\%20reports/EPSL-0611-220-CERU.pdf.

Hirtt, Nico (2005), "Marketization of Education in the Globalized Economy", Paper presented at Worldwide Forum for Comparative Education - Globalization of Education: Government, Market and Society, Beijing Normal University, August 2005, European Conference for Educational Research, Dublin, September 2005, pp.1-9, (Online), http://www.skolo.org/spip.php?article940\&lang=fr

Giddens, Anthony (2001), O mundo na era da globalização, Lisboa, Editorial Presença.

Bauman, Zygmunt (2007), Vida Liquida, Rio de Janeiro, Jorge Zahar Editor Ltda, pp.7-10, (Online), http://www.zahar.com.br/doc/t1132.pdf.

Hall, Stuart (1997), "A centralidade da cultura: notas sobre as revoluções culturais do nosso tempo", Educação \& Realidade, Porto Alegre, 22 (2), pp.15-46, (Online), http://www.educacaoonline.pro.br/index.php?option=com content\&view=article\&id=117:acentralidade-da-cultura-notas-sobre-as-revolucoes-culturais-do-nossotempo\&catid=8:multiculturalismo\&ltemid=19.

Costa, M. Vorraber \& Momo, Mariangela (2009), "Sobre a "conveniência" da escola", Revista Brasileira de Educação, 14 (42), p.525 (Online), http://redalyc.uaemex.mx/src/inicio/ArtPdfRed.jsp?iCve=27512149009.

Magnusson, Johan (2002), Sponsorship in the compulsory schools, An individual assignment in corporate ethics, (Online), http://www.123people.com/s/johan+magnusson.

Sair da Casca (2009), "Acções educativas nas escolas: a comunicação escolar na perspectiva da responsabilidade social", Comunicação Escolar (Online), http://www.sairdacasca.com/comunicacao/com escolar.asp.

Fischer, Rosa M. B. (2002), "O dispositivo pedagógico da mídia: Modos de educar na (e pela) TV", Educação \& Pesquisa, 28 (1), p.153, (Online), http://www.scielo.br/scielo.php?script=sci arttext\&pid=S1517-97022002000100011\&lng=en\&nrm=iso.

Kellner, Douglas (2002), “Lendo imagens criticamente: Em direção a uma pedagogia pós-moderna”, Tomaz Tadeu da Silva (org.), Alienígenas na sala de aula, 4. ${ }^{a}$ ed, Petrópolis, Vozes, p.112 (Online), 
http://pt.scribd.com/doc/54524569/Tomaz-Tadeu-da-Silva-Alienigenas-na-Sala-de-Aula.

Costa, M. Vorraber \& Momo, Mariangela (2009), "Sobre a "conveniência" da escola", Revista Brasileira de Educação, 14 (42), pp.521-533, (Online), http://redalyc.uaemex.mx/src/inicio/ArtPdfRed.jsp?iCve=27512149009

Hall, Stuart (1997), "A centralidade da cultura: Notas sobre as revoluções culturais do nosso tempo" Educação \& Realidade, Porto Alegre, 22 (2) pp.15-46, (Online), http://www.educacaoonline.pro.br/index.php?option=com content\&view=article\&id=117:acentralidade-da-cultura-notas-sobre-as-revolucoes-culturais-do-nossotempo\&catid=8:multiculturalismo\&ltemid $=19$

Afonso, Almerindo J. (2010), "Protagonismos instáveis dos princípios de regulação e interfaces público/privado em educação", Educação \& Sociedade, 31 (113), pp.1137-1156, (Online), http://www.scielo.br/pdf/es/v31n113/05.pdf

Kenway, Jane \& Fitzclarence, Lindsay (1999), "Designing generations: Hybridising entertainment, advertising and education", Australian Journal of Education, 43 (3), 300-317, (Online), http://www.thefreelibrary.com/Designing+generations:+Hybridising+entertainment, +advertising+and...$\underline{\mathrm{a} 062214196}$

Kenway, Jane \& Bullen, Elizabeth (2001), Consuming children: Education-entertainment-advertising, Buckingham, Open University Press, pp.1-7, (Online), http://www.mcgrawhill.co.uk/openup/chapters/0335202993.pdf.

Wilcox, Brian et al (2004), "Psychological implications of commercialism in schools", Report of the APA task force on advertising and children, February 20, pp.55-64, (Online), http://www.apa.org/pi/families/resources/advertising-children.pdf;

Gentili, Pablo (2000), "A McDonaldização da escola: A propósito de "consumindo o outro"', Marisa Vorraber Costa (org.), Escola básica na virada do século: Cultura, política e currículo, São Paulo, Cortez, pp.45-60.

Costa, M. Vorraber (2008), "Paisagens escolares no mundo contemporáneo", Anais, Izabel Viviani Zardo et al (org.), Universidade Regional de Blumenau, SC, Seminário das Licenciaturas, 4-6 Novembro, Blumenau, Edifurb, pp.2-27, (Online), https://www.furb.br/especiais/download/778650757759/driver.pdf;

Momo, Mariangela (2010), "Elementos para se pensar a gestão escolar em uma sociedade de consumo", Espaço Público da Educação: das políticas locais à regulação nacional e transnacional, Actas do I Congresso Ibero-Brasileiro, VI Congresso Luso-Brasileiro em Política/ Administração da Educação e IV Congresso Nacional do Fórum Português de Administração Educacional, Elvas, Portugal, 29-30 Abril, e 01-02 Maio, Cáceres/Mérida, Espanha, (Online), http://www.anpae.org.br/iberolusobrasileiro2010/cdrom/84.pdf

Yúdice, George (2004), A conveniência da cultura -usos da cultura na era global, Belo Horizonte, Universidade Federal de Minas Gerais Editora, pp25-64.

Gentili, Pablo (2000), “A McDonaldização da escola: a propósito de "consumindo o outro"”, Marisa Vorraber Costa (org.), Escola básica na virada do século: Cultura, política e currículo, São Paulo, Cortez, pp.45-60.

Pinto, Manuel (1999), "Os filhos dos media em conflito com a escola e vice-versa", As pessoas que moram nos alunos. Ser jovem, hoje, na escola portuguesa, $5^{\mathrm{a}}$ edição do curso de Verão Colecção Perspectivas Actuais, pp.1-5, (Online), http://www.cursoverao.pt/c 1999/manuelpinto.htm

Molnar, Alex (2006b), School commercialism: From democratic ideal to market commodity, New York, Routledge/Falmer.

Mcneal, James (1992), Kids as customers - A handbook of marketing to children, New York, Lexington Books.

Lipovetsky, Gilles (2007), A felicidade paradoxal. Ensaios sobre a sociedade do hiperconsumo, Lisboa, Edições 70 .

Bauman, Zygmunt (2007), Vida Liquida, Rio de Janeiro, Jorge Zahar Editor Ltda, pp.7-10, (Online), http://www.zahar.com.br/doc/t1132.pdf. 